\title{
BIM, GIS and semantic models of cultural heritage buildings
}

\author{
Pavel Tobiáš \\ Department of Geomatics, Faculty of Civil Engineering \\ Czech Technical University in Prague \\ Thákurova 7, 16629 Prague 6, Czech Republic \\ pavel.tobias@fsv. cvut.cz
}

\begin{abstract}
Even though there has been a great development in using building information models in the AEC (Architecture/Engineering/Construction) sector recently, creation of models of existing buildings is not very common yet. The cultural heritage documentation, in most cases, is still kept in the form of $2 D$ drawings containing only geometry without semantics, attributes or definitions of the relationships and hierarchies between particular building elements. This paper is based on the existing literature and focuses on the historic building information modelling to provide information about the current state of the art. First, a summary of available software is introduced, while not only BIM tools but also related GIS software is considered. This is followed by a review of existing efforts worldwide, while the efforts found are separated into two categories, considering their main focus (3D modelling or resulting data management). The last part of this article is dedicated to the summary of the facts found in the preceding review. The requirements on a resulting information model and the selection of suitable software are discussed and the abilities of BIM and GIS tools are compared.
\end{abstract}

Keywords: BIM; historic building information modelling; GIS; 3D model; cultural heritage.

\section{Introduction}

If we want to perform the tasks related to the administration and maintenance of cultural heritage buildings, we urgently need comprehensive information about the objects of interest. To facilitate this, a large amount of data from various sources and in diverse file formats is to be brought together. Then, an integrated information system, which covers all physical and functional characteristics of a building, can be created. Indeed, the required data can be highly heterogeneous - we are talking about textual and graphical historical documents, plans, maps but also about up-to-date data from structural-historical investigations, geodetic surveys or photographic reconnaissance. Considering that all architectural heritage objects inherently have three-dimensional spatial characteristics, the resulting information system, which will comprise all the mentioned documents, should allow the management of 3D models. Even that might not be sufficient because we often need a $4 \mathrm{D}$ representation of a historic building to describe its changes in time.

Today cultural heritage documentation, in most cases, is still kept in the form of $2 \mathrm{D}$ drawings either digitally or on paper. These drawings often contain only geometric elements without defining semantics or the relationships between particular objects. However, for the purpose 
of facility management and planning reconstructions, the ability to browse a building in a virtual 3D environment and to perform spatial and multi-criteria queries would be convenient. Therefore, it is necessary to know the structure of the building, i.e. the interrelationships between architectural elements, integrate heterogeneous data sources - enrich the elements and thus create a semantic building model.

The creation of semantic building information models (BIM) is currently developing mainly in the field of the design and construction of new buildings (as-designed BIM). Nevertheless, with the use of modern data acquisition methods, such as laser scanning and digital photogrammetry, BIM tools can also be used to develop models of already existing buildings (as-built BIM) [22]. Besides classical BIM software which is used in the AEC (Architecture/Engineering/Construction) sector, we could also use geographic information systems (GIS) tools in the BIM process. Although GIS tools were originally developed to represent larger areas in 2D, they provide sophisticated methods of database storage, relationships definition and attribute and spatial queries creation, which also makes them a suitable tool for the management of information about historic buildings. Moreover, the methods of 3D editing and representation in GIS have also been further developed.

This article investigates, with the use of available literature, the field of historic building information modelling and focuses on the comparison of BIM and GIS tools. First, the existing software for information modelling is summarized. Then, a review of recent efforts is introduced. Last, a discussion that sums up the acquired knowledge is presented. It is necessary to mention that this article expects basic knowledge in the field of BIM. Otherwise see e.g. [24] for more information.

\section{Existing software tools}

Building information modelling is a long-term process which should, in the ideal case, describe a building during its whole life cycle. Numerous stakeholders - experts from various fields participate in the creation of the resulting model. Thus, it is not surprising that there is no single BIM application and the BIM process is rather based on data exchange between particular professionals while each of them uses their dedicated software tool.

The summary of the most important software tools available is in table 1. According to [16], the current BIM software can be separated into three categories:

1. Tools for the design of 3D models (3D modellers)

2. Applications for the viewing and inspection of models

3. Analytical software

Besides the software tools presented in the table, which are more suitable for design and construction, there exists a group of programs utilisable during the longest stage of the building lifecycle, i.e. during its operation and maintenance. Such tools can also be used to manage information about already existing (or even historic) buildings. Here, we are speaking about facility management software, such as ArchiBUS or Graphisoft ArchiFM and, last but not least, about GIS tools, e.g. ESRI ArcGIS.

It is apparent from the table that the leading software companies offer tools which cover most functions needed during the BIM process. These software solutions are then designated for 
commercial use and are, of course, paid. The open source software Edificus Free UPP is one of the few free of charge BIM tools. However, its users have to pay for printing projects and for several tasks third-party applications, which are not free, have to be used, e.g. Trimble SketchUp for 3D modelling. Thus, only BIM viewers with limited functionality, such as Autodesk Navisworks Freedom, can be considered as truly free BIM tools [16].

In the following section, a review of the most important efforts that deal with the information modelling of historic buildings will be introduced. It is worth mentioning that nine out of 16 efforts use the Autodesk Revit software for 3D modelling. This is in accordance with the studies described in the article by David M. Foxe [12] claiming that Revit has a $67 \%$ market share followed by the products by Bentley and Graphisoft.

\section{Recent efforts}

In table 2, there is a list of efforts which use BIM or GIS to create information models of cultural heritage buildings. The basis for this enumeration was found in the article by Saygi and Remondino [22] and it was modified and further extended with other works found. Although this list is definitely not complete, it allows studying the approaches and tools used quite well.

The efforts on the list can be separated into categories considering the chosen approach. The majority of the efforts are rather focused on the use of BIM software. In these cases a library of parametric objects is usually developed. Such a library is usable for the conversion of an unstructured point cloud, generated by laser scanning, into the form of a parametric 3D model.

The second group of efforts uses a combination of BIM and GIS tools while BIM is usually used to create 3D models and GIS to manage the resulting information. The last category can be described as the GIS approach because no classical BIM software is used. However, the workflow is very similar to the combined BIM/GIS way. In the two following sections we will describe particular efforts in greater detail.

\section{The efforts focused on 3D modelling}

The creation of a 3D model must be preceded by data collection. Currently laser scanning and digital photogrammetry are understood as modern methods of data acquisition. The result of laser scanning is a dense point cloud. Although this point cloud can be used for some preservation purposes, it is hardly a full-fledged 3D model. Therefore, it is no surprise that there are a lot of efforts dealing with the conversion of the acquired data from the point cloud into a parametric 3D model. For example, the work by Fai et al. [11] is focused on problems bound with combining laser scanning data and 3D models from BIM modelling software. However, this work uses generic object libraries which are not adapted for the specific needs of historic buildings.

The creation of a prototype library designed specifically for the needs of the cultural heritage preservation was first described in the article by Murphy et al. [19] while it was named Historic Building Information Modelling (HBIM). This method was further developed in the paper [18]. The HBIM process begins with the creation of data sets using terestrial laser scanning and photogrammetry. The next stage involves the design and development of a particular 
Table 1: Commercial and open-source BIM tools (modified from [16])

\begin{tabular}{|c|c|c|c|}
\hline Product Name & Manufacturer & BIM Use & Primary Function \\
\hline Revit Architecture & Autodesk & $\begin{array}{l}\text { Creating and reviewing } \\
3 \mathrm{D} \text { models }\end{array}$ & $\begin{array}{l}\text { Architectural modelling } \\
\text { and parametric design }\end{array}$ \\
\hline Bentley Architecture & Bentley Systems & $\begin{array}{l}\text { Creating and reviewing } \\
3 \mathrm{D} \text { models }\end{array}$ & Architectural Modelling \\
\hline SketchUp Pro & Trimble & $\begin{array}{l}\text { Conceptual 3D mod- } \\
\text { elling }\end{array}$ & $\begin{array}{l}\text { Conceptual design mod- } \\
\text { elling }\end{array}$ \\
\hline ArchiCAD & Graphisoft & $\begin{array}{l}\text { Conceptual 3D architec- } \\
\text { tural model }\end{array}$ & $\begin{array}{l}\text { Architectural model cre- } \\
\text { ation }\end{array}$ \\
\hline TeklaStructures & Tekla & $\begin{array}{l}\text { Conceptual 3D mod- } \\
\text { elling }\end{array}$ & $\begin{array}{l}\text { Architectural 3D model } \\
\text { application }\end{array}$ \\
\hline DProfiler & Beck Technology & $\begin{array}{l}\text { Conceptual design and } \\
\text { cost estimation }\end{array}$ & $\begin{array}{l}3 \mathrm{D} \text { conceptual modelling } \\
\text { with real-time cost esti- } \\
\text { mation }\end{array}$ \\
\hline Vectorworks Designer & Nemetschek & $\begin{array}{l}\text { Conceptual } 3 \mathrm{D} \text { mod- } \\
\text { elling }\end{array}$ & $\begin{array}{l}\text { Architectural model cre- } \\
\text { ation }\end{array}$ \\
\hline Affinity & Trelligence & $\begin{array}{l}\text { Conceptual } 3 \mathrm{D} \text { mod- } \\
\text { elling }\end{array}$ & Early concept design \\
\hline Edificus & AccaSoftware & $\begin{array}{l}\text { Architectural BIM de- } \\
\text { sign and } 3 \mathrm{D} \text { object CAD }\end{array}$ & Architectural modelling \\
\hline Vico Office & Vico Software & $\begin{array}{l}\text { Conceptual 5D mod- } \\
\text { elling }\end{array}$ & $\begin{array}{l}\text { 5D conceptual model, } \\
\text { cost and schedule data }\end{array}$ \\
\hline Revit Structure & Autodesk & Structural & $\begin{array}{l}\text { Structural modelling } \\
\text { and parametric design }\end{array}$ \\
\hline $\mathrm{SDS} / 2$ & Design Data & Structural & $\begin{array}{l}\text { 3D structural modelling } \\
\text { and detailing }\end{array}$ \\
\hline RISA & RISA Technologies & Structural & $\begin{array}{l}\text { Full suite of structural } \\
\text { design applications }\end{array}$ \\
\hline Robot & Autodesk & Structural analysis & $\begin{array}{l}\text { Bi-directional link with } \\
\text { Revit Structure }\end{array}$ \\
\hline Green Building Studio & Autodesk & Energy analysis & $\begin{array}{l}\text { Energy use and carbon } \\
\text { footprint calculation }\end{array}$ \\
\hline $\begin{array}{l}\text { Structural Analysis, De- } \\
\text { sign Detailing, Building } \\
\text { Performance }\end{array}$ & Bentley Systems & $\begin{array}{lr}\text { Structural } & \text { analysis, } \\
\text { detailing, } & \text { quantity } \\
\text { take-off, building perfor- } & \\
\text { mance } & \end{array}$ & $\begin{array}{l}\text { Measures, assess and re- } \\
\text { ports building perfor- } \\
\text { mance }\end{array}$ \\
\hline Solibri Model Checker & Solibri & $\begin{array}{l}\text { Model checking and val- } \\
\text { idation }\end{array}$ & $\begin{array}{l}\text { Rule based checking for } \\
\text { compliance and valida- } \\
\text { tion of all objects in } \\
\text { model }\end{array}$ \\
\hline Tekla BIMSight & Tekla & Model Viewer & $\begin{array}{l}\text { Models combination, } \\
\text { clashes checking }\end{array}$ \\
\hline $\begin{array}{l}\text { Navisworks } \quad \text { Man- } \\
\text { age/Simulate }\end{array}$ & Autodesk & $\begin{array}{l}\text { Model checking and val- } \\
\text { idation }\end{array}$ & $\begin{array}{l}\text { Clashes checking, } 4 \mathrm{D} \\
\text { simulations of construc- } \\
\text { tion progress }\end{array}$ \\
\hline xBIMXplorer & Open BIM & IFC Viewer & $\begin{array}{l}\text { IFC files opening and } \\
\text { viewing }\end{array}$ \\
\hline Solibri Model Viewer & Solibri & Model viewer & $\begin{array}{l}\text { IFC files opening and } \\
\text { viewing }\end{array}$ \\
\hline Navisworks Freedom & Autodesk & Model viewer & $\begin{array}{l}\text { IFC files opening and } \\
\text { viewing }\end{array}$ \\
\hline
\end{tabular}

library of parametric objects. To fulfill this task the software platform Graphisoft ArchiCAD and the open-source scripting language GDL (Geometric Description Language), which is implemented in ArchiCAD, were used. After the creation of the library, a semi-automatic process of mapping parametric objects into point clouds facilitates the $3 \mathrm{D}$ model creation.

Furthermore, Oreni et al. [20], Appolonio et al. [2] or Brumana et al. [6] in their articles also deal with the creation of historic building-specific libraries. All the mentioned accepted 
Table 2: Current efforts dealing with the modelling of historic buildings (extended from [22])

\begin{tabular}{|c|c|c|c|c|}
\hline Approach & Reference paper(s) & Applied case & Software & Notes \\
\hline BIM & $\begin{array}{l}\text { Garagnani }(2012) \\
{[13]}\end{array}$ & $\begin{array}{l}\text { An early Byzantine } \\
\text { church in Ravenna }\end{array}$ & $\begin{array}{ll}\text { Autodesk } & \text { Revit Ar- } \\
\text { chitecture, } & \text { GreenSpi- } \\
\text { der plugin } & \end{array}$ & $\begin{array}{l}\text { A plugin facilitating segmen- } \\
\text { tation of unstructured point } \\
\text { clouds }\end{array}$ \\
\hline BIM & $\begin{array}{l}\text { Attar et al. (2010) } \\
{[3]}\end{array}$ & 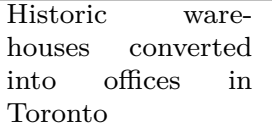 & $\begin{array}{l}\text { Autodesk Revit, Auto- } \\
\text { CAD, pluginy gbXML, } \\
\text { EnergyPlus }\end{array}$ & $\begin{array}{l}\text { Evaluation/analysis of building } \\
\text { performance and energetic effi- } \\
\text { ciency }\end{array}$ \\
\hline BIM & $\begin{array}{l}\text { Achille et al. } \\
(2012)[1]\end{array}$ & $\begin{array}{l}\text { The main spire of } \\
\text { the Milan cathe- } \\
\text { dral }\end{array}$ & $\begin{array}{l}\text { Rhinoceros, WebGL, } \\
\text { Back Office, Front Of- } \\
\text { fice, plugin Pointools }\end{array}$ & $\begin{array}{l}\text { The model used as a repository } \\
\text { containing photographic cata- } \\
\text { logue. Ability of sharing on the } \\
\text { web }\end{array}$ \\
\hline BIM & $\begin{array}{l}\text { Oreni et al. (2013) } \\
{[20]}\end{array}$ & $\begin{array}{l}\text { Various types of } \\
\text { historic vaults }\end{array}$ & $\begin{array}{l}\text { Leica Cloudwork, Au- } \\
\text { todesk Revit, Auto- } \\
\text { CAD, Rhinoceros }\end{array}$ & Parametric models of vaults \\
\hline BIM & $\begin{array}{lll}\text { Apollonio } & \text { et } & \text { al. } \\
(2012)[2] & & \end{array}$ & $\begin{array}{l}\text { Palladian architec- } \\
\text { ture - doric order }\end{array}$ & Autodesk Revit & $\begin{array}{l}\text { Libraries of parametric objects } \\
\text { based on classical architectural } \\
\text { literature }\end{array}$ \\
\hline BIM & $\begin{array}{lll}\text { Boeykens } & \text { et } & \text { al. } \\
(2012)[5] & & \end{array}$ & $\begin{array}{l}\text { The Prague Vi- } \\
\text { nohrady synagogue }\end{array}$ & $\begin{array}{l}\text { Graphisoft ArchiCAD, } \\
\text { Maxon, Cinema4D }\end{array}$ & $\begin{array}{l}\text { Reconstruction of a no longer } \\
\text { existing synagogue with the use } \\
\text { of BIM }\end{array}$ \\
\hline BIM & $\begin{array}{l}\text { Fai et al. (2011) } \\
{[11]}\end{array}$ & $\begin{array}{l}\text { Historic factory } \\
\text { areal in Toronto }\end{array}$ & $\begin{array}{l}\text { AutoCAD, Civil 3D, } \\
\text { SketchUp, Revit, Nav- } \\
\text { isworks }\end{array}$ & 4D modelling \\
\hline BIM & Foxe (2010) [12] & $\begin{array}{l}\text { Historic buildings } \\
\text { in Boston and } \\
\text { Durham }\end{array}$ & $?$ & $\begin{array}{l}\text { The resulting information mod- } \\
\text { els used as a basis for recon- } \\
\text { struction. }\end{array}$ \\
\hline BIM & $\begin{array}{lll}\text { Brumana } & \text { et } & \text { al. } \\
(2013)[6] & & \end{array}$ & $\begin{array}{l}\text { A church in Scaria } \\
\text { d'Intelvi, Italy }\end{array}$ & $\begin{array}{l}\text { Autodesk Revit, Au- } \\
\text { todesk Green Building } \\
\text { Studio }\end{array}$ & $\begin{array}{l}\text { Different construction phases } \\
\text { captured in the BIM model } \\
\text { (stratigraphy). The model fur- } \\
\text { ther used for energetic efficiency } \\
\text { analyses. }\end{array}$ \\
\hline BIM & $\begin{array}{l}\text { Baik et al. (2014) } \\
{[4]}\end{array}$ & $\begin{array}{l}\text { Historic buildings } \\
\text { in Jeddah, Saudi } \\
\text { Arabia }\end{array}$ & $\begin{array}{l}\text { PhotoModeler Scan- } \\
\text { ner, Autodesk RECAP } \\
360, \quad \text { Rhinoceros, } \\
\text { Autodesk Revit }\end{array}$ & $\begin{array}{l}\text { Library of parametric objects } \\
\text { (JHBIM) }\end{array}$ \\
\hline BIM/GIS & $\begin{array}{l}\text { Yajing and Cong } \\
(2011) \text { [26] }\end{array}$ & $\begin{array}{l}\text { The stone heritage } \\
\text { of Kao temple }\end{array}$ & $\begin{array}{l}\text { Autodesk } \\
\text { 3ds Max rit and } \\
\text { SketchUp, Geomagic, } \\
\text { AutoCAD }\end{array}$ & $\begin{array}{l}\text { Revit families for heritage } \\
\text { buildings of stone } A \text { GIS and } \\
\text { BIM connection for manage- } \\
\text { ment purposes planned. }\end{array}$ \\
\hline BIM/GIS & $\begin{array}{l}\text { San José-Alonso et } \\
\text { al. (2009) [21] }\end{array}$ & $\begin{array}{l}\text { Various heritage } \\
\text { object in Spain }\end{array}$ & PINTA & 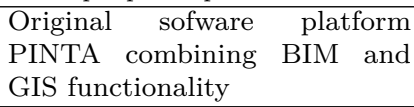 \\
\hline BIM/GIS & $\begin{array}{l}\text { Dore and Murphy } \\
\text { (2012) [9], Murphy } \\
\text { et al. (2013) [18] }\end{array}$ & $\begin{array}{l}\text { Henrietta Street in } \\
\text { Dublin }\end{array}$ & $\begin{array}{l}\text { Graphisoft ArchiCAD, } \\
\text { SketchUp + CityGML } \\
\text { plugin, ArcGIS }\end{array}$ & $\begin{array}{l}\text { Comprehensive workflow of } 3 \mathrm{D} \\
\text { model creation based on laser } \\
\text { scanning and a library of para- } \\
\text { metric objects, export into the } \\
\text { GIS environment for the pur- } \\
\text { pose of data management. }\end{array}$ \\
\hline BIMxGIS & $\begin{array}{l}\text { Saygi and } \text { Re- } \\
\text { mondino }(2013) \\
{[22], \quad \text { Saygi et al. }} \\
(2013)[23]\end{array}$ & $\begin{array}{l}\text { Kurşunlu Khan in } \\
\text { Turkey }\end{array}$ & $\begin{array}{l}\text { Autodesk } \text { Revit Ar- } \\
\text { chitecture }+ \text { Revit } \\
\text { DB Link, AutoCAD, } \\
\text { SketchUp, 3ds Max, } \\
\text { ArcGIS, PostGIS }\end{array}$ & $\begin{array}{l}\text { Comparison between the BIM } \\
\text { and the GIS approach }\end{array}$ \\
\hline GIS & $\begin{array}{l}\text { Centofanti et al. } \\
(2011)[7]\end{array}$ & $\begin{array}{l}\text { Villa and churches } \\
\text { in Italy }\end{array}$ & $\begin{array}{l}\text { AutoCAD, 3ds Max, } \\
\text { Rhinoceros, Rapidform } \\
\text { XOR, Microsoft Ac- } \\
\text { cess, ArcGIS }\end{array}$ & $\begin{array}{l}\text { 3D models in the GIS envi- } \\
\text { ronment, heritage information } \\
\text { management and analyses }\end{array}$ \\
\hline GIS & $\begin{array}{l}\text { Jedlička et al. } \\
(2013)[15]\end{array}$ & The castle Kozel & $\begin{array}{l}\text { Kokeš, RiSCAN, Mi- } \\
\text { croStation, MSR, } \\
\text { SketchUp, ArcGIS, } \\
\text { City Engine }\end{array}$ & $\begin{array}{l}\text { Comprehensive workflow from } \\
\text { data acquisition to import into } \\
\text { GIS for further analyses }\end{array}$ \\
\hline
\end{tabular}



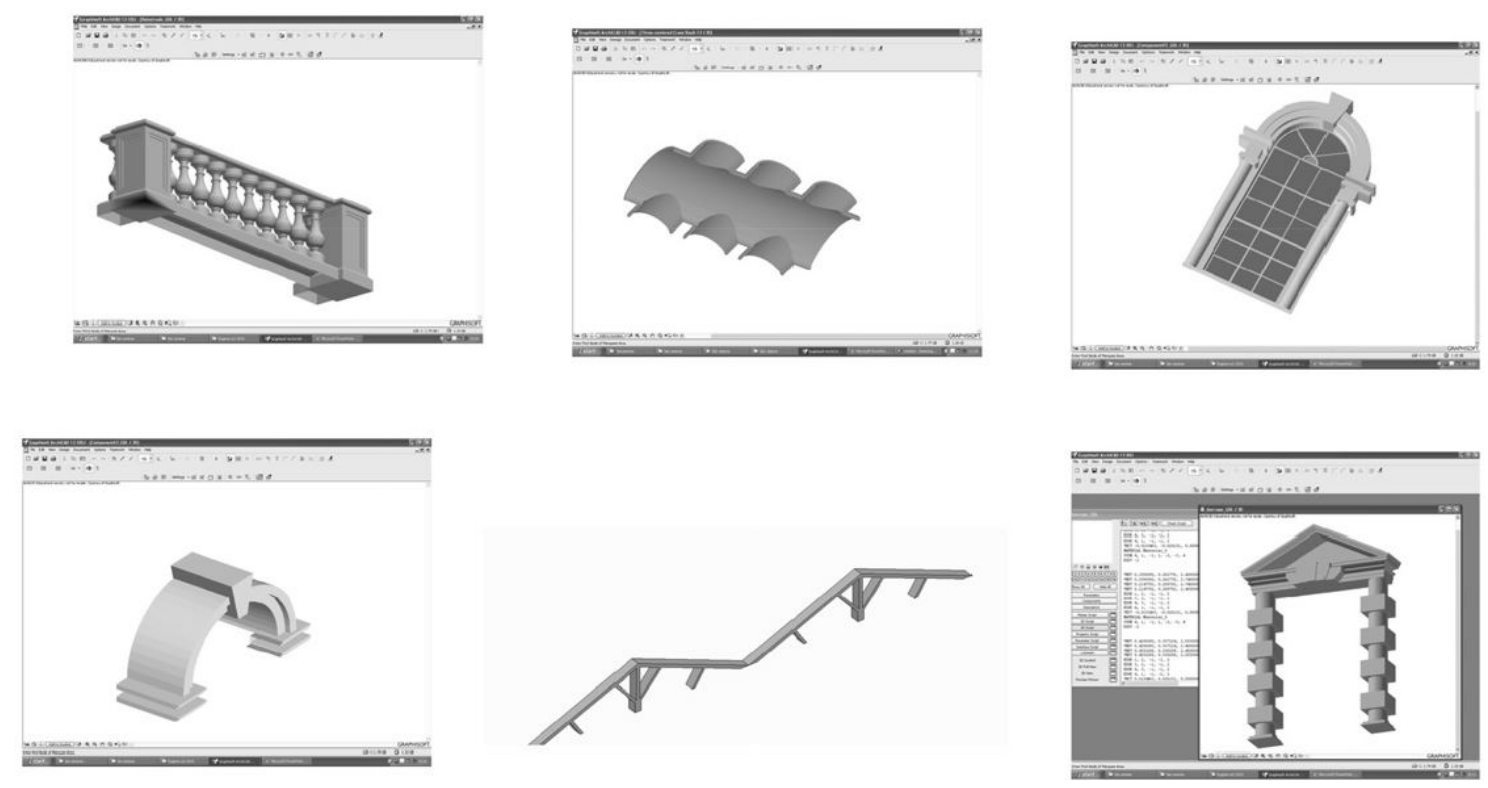

Figure 1: Examples of parametric objects from the HBIM library [18]

the term HBIM. However, it is not clear whether it only describes parametric libraries or the whole modelling process in general. Baik et al. [4], whose paper describes a library specifically designed for the modelling of the Middle East architecture, use the localised term JHBIM (Jeddah Historical Building Information Modelling). Also the work by Yajing and Cong [26] could belong to this group. Even though they do not use the HBIM term, they similarly create their own object library to model stone heritage buildings. Last but not least, Garagnani [13] deals with the description of his plugin GreenSpider, which was developed to facilitate the processing of unstructured point clouds. All the efforts mentioned in this article use, compared to Murphy et al., the BIM tool Autodesk Revit.

Not all the efforts use laser scanning data as a basis for 3D modelling. Saygi et al. [22, 23] compare the BIM and the GIS approach to 3D modelling and data management and use archival drawings as their base. Particular elements are then created manually in a suitable 3D modelling software. Autodesk Revit was used to try out the BIM approach and a combination of tools (AutoCAD, Trimble SketchUp and Autodesk 3ds) to examine the possibilities of the GIS processing. Also Boeykens et al. [5] utilise existing documentation in the form of drawings. Laser scanning as a data acquisition method is in their case, of course, out of the question because they model an already non-existent building.

\section{The efforts focused on data management}

Even though the research by Saygi et al. [22, 23] was already mentioned in the previous section because it also deals with 3D modelling, its main topic is the analysis of heritage data storage and management. Their articles evaluate the workflows of semantic model creation and storage in detail. The necessity of the 3D model segmentation into particular architectural elements is emphasized because information about each building component can only be stored this way. The possibilities of $3 \mathrm{D}$ geometry management and additional information storage 

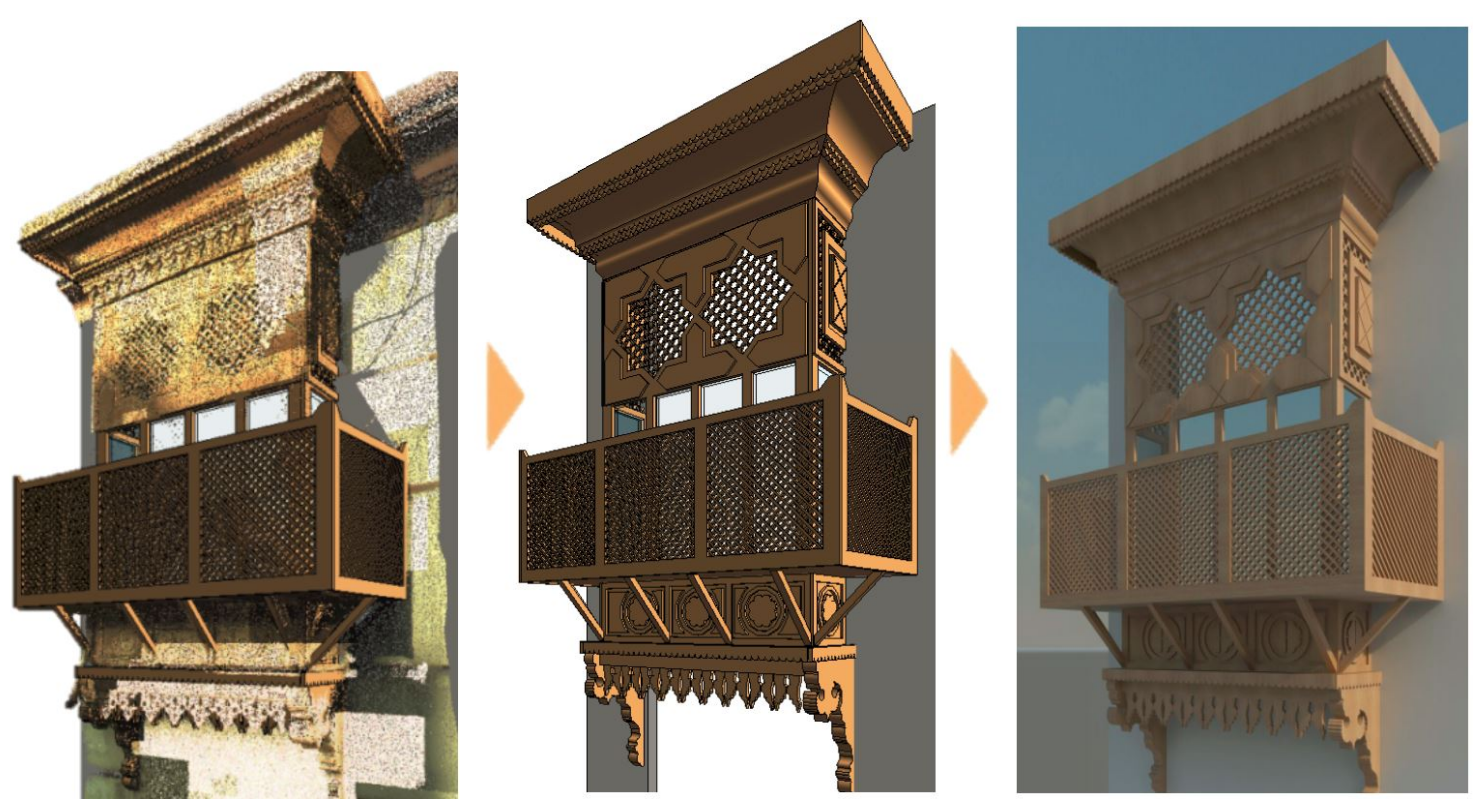

Figure 2: Creation and visualisation of a 3D model based on a point cloud [4]

are evaluated and GIS software (ArcGIS tested) is identified as a currently more suitable tool because of its capabilities of non-homogeneous data aggregation and non-spatial information integration.

The aforementioned is also acknowledged in the article by Dore and Murphy [9], in which the integration of a 3D model, resulting from the HBIM process, into the GIS environment is described. The resulting model should serve as a basis for information management and interconnection with other data sources including external sources, i.e. other information systems. The Trimble SketchUp application with an appropriate CityGML plugin facilitates here the conversion between the BIM software ArchiCAD and the GIS tool ArcGIS. A very similar approach is used in the work by Jedlička et al. [15] though they do not use any actual BIM software.

The same tool, i.e. ArcGIS, is also utilized in the work by Centofanti et al. [7] in order to create an architectural information system specifically designed for the purposes of cultural heritage management and maintenance. This work also states that current BIM software is still immature for the tasks of heritage preservation. Thus, GIS tools are preferred at least for data management. A similar information system is presented in the paper by San José-Alonso et al. [21] where it is named the Cultural Heritage Information System (CHIS). Since the authors had found the currently available software tools insufficient, a new platform called PINTA (Processing INformation sysTem for Architecture) was developed. The PINTA software enables creating a model from laser scanning and digital photogrammetry data, store it and automatically generate drawings and cut sections. The most interesting is then the emphasis on the remote access of users from the ranks of the government and general public (which is aligned with the spirit of BIM cooperation).

Despite the papers mentioned above that prefer the use of GIS for data management, there exist several other works employing exclusively BIM tools. The articles by Foxe [12] or 


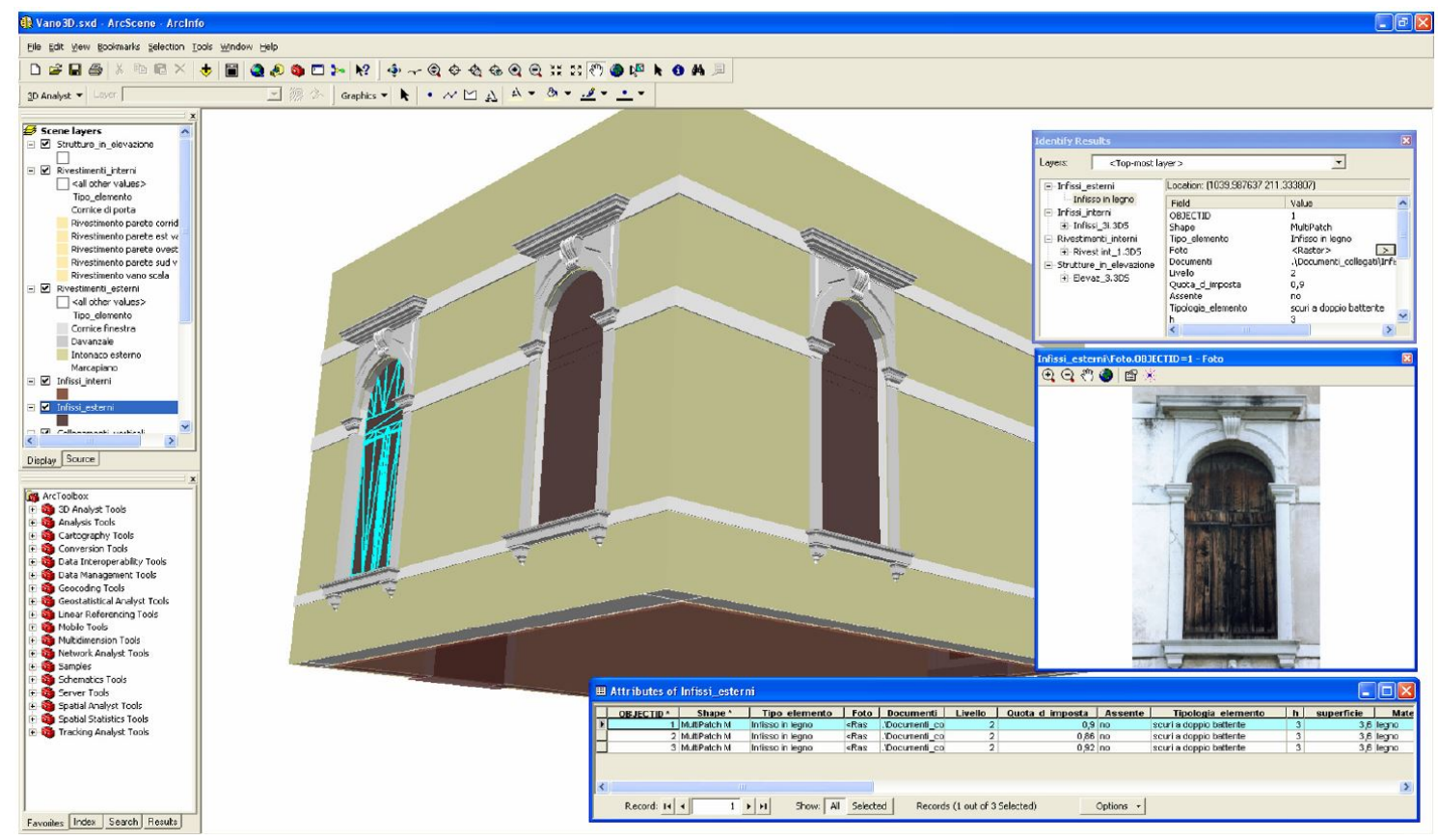

Figure 3: 3D model of a heritage bulding in the GIS environment [7]

Attar et al. [3] can be such examples while they describe efforts utilizing BIM for planning reconstructions or energy efficiency analyses. Nevertheless, it should be noted that both papers are focused on heritage buildings in North America which are significantly newer than is usual in Europe. Therefore, they are structurally much closer to modern buildings which BIM was designed for. A similar situation is depicted in the contribution by Fai et al. [11]. Here, the BIM software is used to plan the reconstruction of a defunct factory and shows its strength in 4D modelling, i.e. the ability to capture changes over time. Finally, Brumana et al. [6] also utilise BIM to visualise different constructive phases in 3D (stratigraphy - see fig. $4)$.

\section{Discussion}

This section will summarize the most important questions which come out during the historic building information modelling process and will be based on the aforementioned literature. First, it is necessary to realise that BIM workflows, currently relatively well developed in the AEC sector, are in most cases focused on the design and construction of new buildings. The requirements on the creation of existing building models may be significantly different. Speaking about historic cultural heritage buildings the situation is even more difficult because such buildings contain a lot of irregular architectural elements which can be damaged or wornout. The requirements on data management are also very high because the resulting $3 \mathrm{D}$ model has to comprise a large amount of heterogeneous data sources.

\section{The requirements on an information model}

The resulting 3D model should contain semantics, characteristics of the object structure and relationships between particular architectural elements [22]. Therefore, during the modelling 


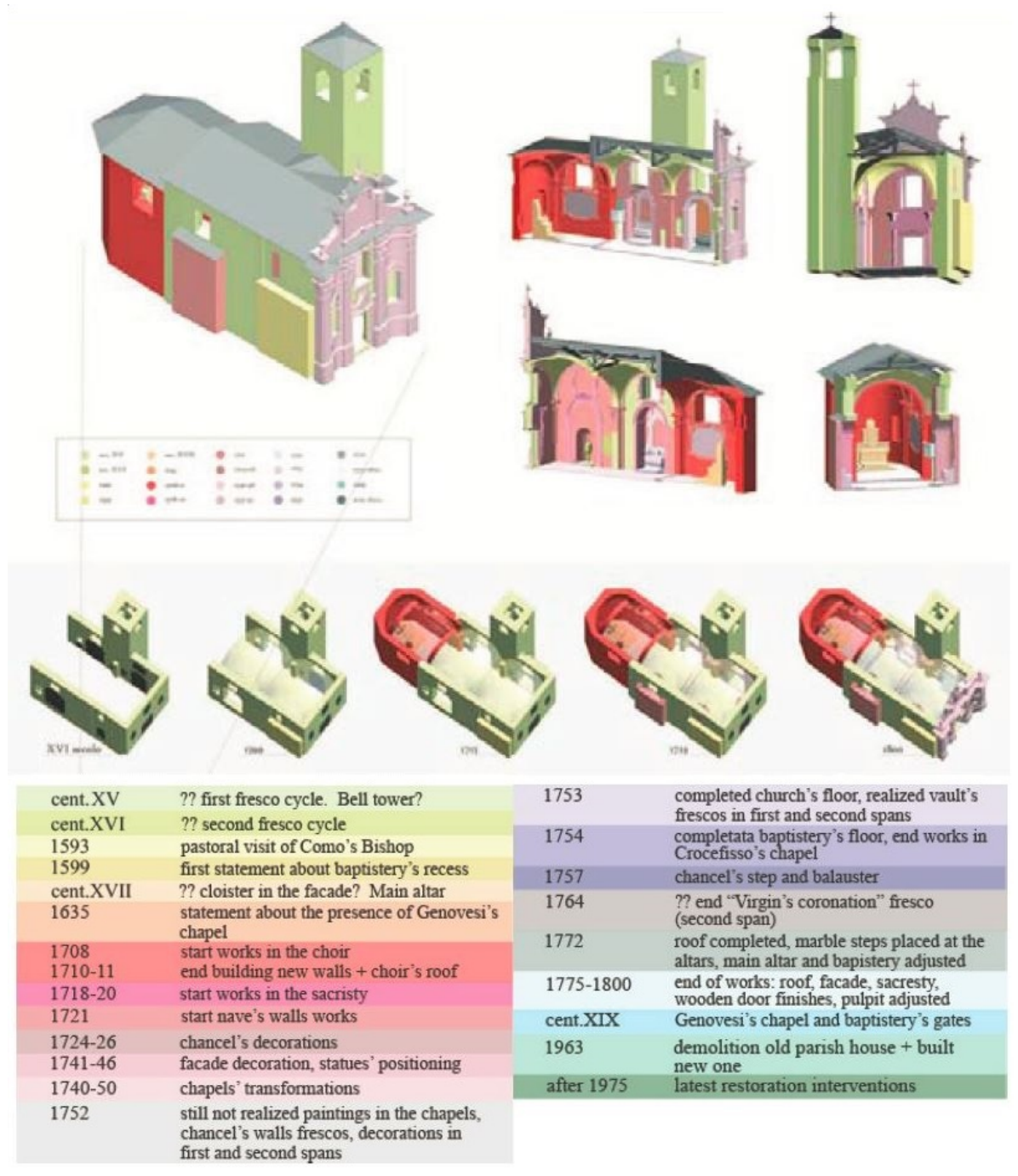

Figure 4: Architectural elements differentiated by particular constructive phases [6]

stage capturing only visible surfaces is not sufficient and we also have to model the "detail behind the object's surfac", i.e. concern methods of construction and materials of architectural elements [18].

On the other hand, it is necessary to consider what level of detail is suitable for our needs. Foxe in his article [12] reminds that in the case of an existing building its model is always to a certain extent different from the actual object. There is always a certain level of simplification and abstraction and too much detail can also be inappropriate considering the increasing amounts of data which must be processed during further work with the model. Moreover, it is worth mentioning that the level of detail does not only apply to geometry but it is also related to the accuracy of attributes - descriptive information. In this context, the term level of development is more suitable. This term was first used by the American Institute of Architects (AIA) in 2008 and expresses the model detail with 5 values $(100-500)$ [8]. In figure 5, there is a slightly simplified depiction of LOD by Foxe. Although the levels of development were originally designed for newly built buildings, they can also be applied to 
historic buildings especially if their reconstruction is planned. What LOD we want to achieve should be carefully thought out so that the model structure allows further addition of details.

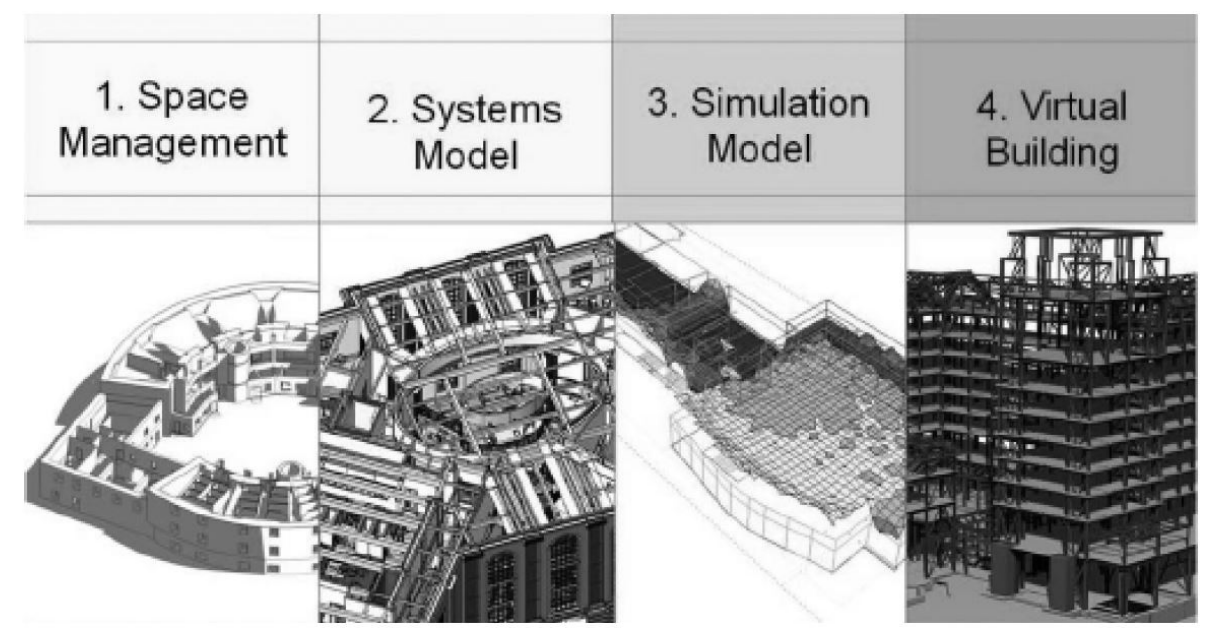

Figure 5: The levels of BIM according to [12]

3D geometric models which depict current as-found physical characteristics of heritage buildings can be considered as the primary result for the needs of cultural heritage preservation. However, descriptive information must also be integrated to meet the requirements of BIM. In the result, the following data will be included $[7,17]$ :

1. Building location and identification - coordinates in the national coordinate system, cadastral information (number of the building, land parcel number, owner, mode of building using... )

2. Historical documents

- textual documents - historical review - history of the building, archival sources, chronicles, transcriptions...

- raster data - old maps, plans, archival photographs and other image material

3. Architectural analysis of the building - used material, construction systems, information about particular building elements, construction history, differentiation of structures according construction stages, art-historical and aesthetic evaluation of parts of the building

4. Information about the condition of the building - closely related to the previous item

- textual documents from surveys - used materials, construction techniques, condition, damage and structural problems

- raster data from surveys - drawings, photographs, photoplans, maps

- vector data from surveys - documentation created during the geodetic survey (site plans, elevations, sections, floor plans...)

5. Information about reconstructions, maintenance and other interventions - in raster or vector formats

Geoinformatics FCE CTU 15(2), 2016 
It is clear from the list above that the results of the structural-historical investigation [17] are a crucial data source for the creation of HBIM in the Czech Republic.

The resulting models of historic buildings will be an integral part of an information system. The required functionality of this information system can be summarized as follows $[22,18$, 7]:

1. The ability to define the interrelationships and hierarchies between the objects of the model

2. Management of descriptive information - attribute data which the model is enhanced by

3. $4 \mathrm{D}$ representation - the ability to represent temporal data

4. Tools for 3D editing

5. $2 \mathrm{D}$ and $3 \mathrm{D}$ visualisation at suitable scales

6. The capability to browse attribute data, photographs and other documents

7. The interface for asking attribute, spatial and multi-criteria queries

8. Automatic export into the form of documentation suitable for planning of reconstructions and historical studies

\section{The selection of suitable tools}

To be able to create and manage an information model, the right choice of software tools is crucial. Unfortunately, today there is no comprehensive solution specifically designed to model and manage semantically enhanced 3D models of historic buildings [22]. The currently available approaches to spatial information management, i.e. BIM and GIS, have both their pros and cons (see fig. 3), therefore, we cannot definitely prioritize one of them. Thus, meanwhile it will be necessary to employ both solutions, combine suitable software tools and utilise their advantages.

Table 3: The comparison of BIM and GIS capabilities [22]

\begin{tabular}{|l|c|c|}
\hline Criteria for Information Management Process & BIM & GIS \\
\hline Definition of specified mutual and hierarchical relationships & X & $\checkmark$ \\
\hline Enhanced attribute management & X & $\checkmark$ \\
\hline 3D editing functionalities & $\checkmark$ & X \\
\hline Spatial and multi-criteria query-able characteristics & X & $\checkmark$ \\
\hline Representation of multi-layered conceptual themes in 3D & $\checkmark$ & X \\
\hline Temporal (4D) representations & $\checkmark$ & $\checkmark$ \\
\hline
\end{tabular}

The most important advantage of BIM is the ability to create 3D models using intelligent parametric elements. On the other hand, existing libraries of parametric objects are generally not suitable for the 3D reconstruction of heritage buildings because in such buildings even objects of the same type (walls, columns... ) can be highly different in shape because of missing industrialisation and prefabrication in the past. Furthermore, the definition of the heritage preservation-specific attributes, integration of non-homogeneous datasets and possibilities of 
asking spatial queries are limited in BIM [22, 23, 18]. Nevertheless, despite these drawbacks, BIM remains a very powerful tool for the modelling phase. The design of new libraries which facilitate conversion from unstructured point clouds into the form of volumetric 3D models is then a very frequent topic of scientific works $[20,2,6,4,26,18,19]$.

GIS, on the other hand, has been primarily designed to manage and query spatial information. In the GIS environment we can easily work with semantically enriched objects, non-geometric attributes can be linked with geometry and managed in relational databases. Spatial and attribute queries can be asked. However, the possibilities of 3D editing are still rather limited. Thus, it is no surprise that the most efficient workflow remains the aforementioned combination of BIM tools for 3D modelling and GIS tools for data management $[22,23,26,21,9$, $15]$.

In the context of BIM the term of parametric modelling is often mentioned while it is necessary to realise that there are more approaches to parametric reconstruction of buildings. What approach is suitable for our needs depends mostly on our input data. Classic BIM software is an advanced 3D CAD tool which utilises intelligent parametric objects. These objects represent all physical and functional properties of real-world architectural elements. In addition, interrelationships between the elements can be defined. If we can obtain building documentation in the form of $2 \mathrm{D}$ drawings, we can create a virtual 3D model manually from the elements (see e.g. [22]).

A slightly different type of parametric modelling can be used to process the laser scanning or digital-photogrammetry data. If we have a parametric library prepared, we can automate the process of mapping vector data onto point clouds. The library can be created based on historical architectural books and it contains a textual description of particular elements in a text file, e.g. with the use of the GDL language. The architectural elements are then semiautomatically identified in point clouds and a discrete model can be replaced with continuous geometric primitives [18].

Lastly, the procedural modelling of buildings with the use of shape grammars can be understood as a type of parametric modelling. This approach is similar to the previous mentioned because it employs a textual, human-readable description of architecture. The creation of models is based on different architectural styles. Buildings are divided into parts and represented by a set of basic shapes. These shapes are controlled by replacement rules while each shape can be replaced with more detailed shapes or it can be changed by a transformation. Although procedural modelling was developed to create models of larger urban areas and for visualisation purposes $[14,25]$, it might also be a suitable method for $3 \mathrm{D}$ reconstructions of single buildings if the 2D drawings are available [10]. Furthermore, the focus on semantics and defining objects hierarchies is very similar to BIM.

\section{Conclusion}

The goal of this review was to summarize recent efforts dealing with the information modelling of cultural heritage buildings and to compare the abilities of BIM and GIS for this purpose. Today, there is no comprehensive software solution designed specifically for creating and managing information about historic buildings, i.e. for the whole workflow of processing measured data and other data sources, 3D modelling, management of the resulting model, analyses and visualisations. This is apparent from the review because most of the existing 
works utilise a combination of several BIM and GIS software tools.

The existing efforts can be divided in two parts according to the approach used. BIM tools are currently employed mainly for 3D modelling based on laser-scanning and photogrammetry data. The design of parametric libraries and conversion from an unstructured point cloud into a continuous model are very important topics here. GIS, on the other hand, is used mainly for the management of the resulting models and establishing connections with descriptive attributes or even other information systems. However, the question of transformation from BIM into the GIS environment seems to be still not fully resolved.

\section{Acknowledgements}

This work was supported by the Grant Agency of the Czech Technical University in Prague, grant No. SGS16/063/OHK1/1T/11 "Innovative Approaches in the Field of Geomatics: Data Collection, Processing and Analyses".

\section{References}

[1] C. Achille, F. Fassi, and L. Fregonese. "4 Years history: From 2D to BIM for CH: The main spire on Milan Cathedral". In: 2012 18th International Conference on Virtual Systems and Multimedia (VSMM). Sept. 2012, pp. 377-382. DOI: 10.1109/VSMM. 2012. 6365948.

[2] Fabrizio Ivan Apollonio, Marco Gaiani, and Zheng Sun. "BIM-based Modeling and Data Enrichment of Classical Architectural Buildings". Italian. In: SCIRES-IT 2.2 (Dec. 2012), pp. 41-62. ISSN: 2239-4303. DOI: 10.2423/i22394303v2n2p41.

[3] Ramtin Attar et al. "210 King Street: A Dataset for Integrated Performance Assessment". In: Proceedings of the 2010 Spring Simulation Multiconference. SpringSim '10. San Diego, CA, USA: Society for Computer Simulation International, 2010, 177:1-177:4. ISBN: 978-1-4503-0069-8. DOI: 10.1145/1878537.1878722.

[4] A. Baik et al. "Jeddah Historical Building Information Modelling "JHBIM" -Object Library". In: ISPRS Annals of Photogrammetry, Remote Sensing and Spatial Information Sciences II-5 (May 2014), pp. 41-47. ISSN: 2194-9050. DOI: 10.5194/isprsannals-II5-41-2014.

[5] Stefan Boeykens, Caroline Himpe, and Bob Martens. "A Case Study of Using BIM in Historical Reconstruction. The Vinohrady Synagogue in Prague". In: Digital Physicality / Physical Digitality. eCAADe and CVUT, Faculty of Architecture, Sept. 2012, pp. 729-738. ISBN: 978-9-4912070-3-7. URL: https://lirias.kuleuven. be/handle/ 123456789/350340 (visited on 02/02/2016).

[6] Raffaella Brumana et al. "From survey to HBIM for documentation, dissemination and management of built heritage: The case study of St. Maria in Scaria d'Intelvi". English. In: The Institute of Electrical and Electronics Engineers, Inc. (IEEE) Conference Proceedings. Vol. 1. Piscataway: The Institute of Electrical and Electronics Engineers, Inc. (IEEE), Oct. 2013, p. 497. URL: http://search.proquest.com/docview/1565886446 (visited on $02 / 02 / 2016$ ).

Geoinformatics FCE CTU 15(2), 2016 
[7] M. Centofanti et al. "The architectural information system SIArch3D-univaq for analysis and preservation of architectural heritage". English. In: International Archives of the Photogrammetry, Remote Sensing and Spatial Information Sciences - ISPRS Archives 38.5 (Sept. 2011), pp. 9-14. ISSN: 1682-1750.

[8] Martin Černý. BIM př́ručka. Praha: Odborná rada pro BIM o.s., 2013. ISBN: 978-80260-5296-8.

[9] C. Dore and M. Murphy. "Integration of Historic Building Information Modeling (HBIM) and 3D GIS for recording and managing cultural heritage sites". In: IEEE, Sept. 2012, pp. 369-376. ISBN: 978-1-4673-2564-6, 978-1-4673-2563-9. DOI: 10 . 1109/VSMM . 2012. 6365947.

[10] Kristinn Nikulás Edvardsson. "3d GIS modeling using ESRI's CityEngine, A case study from the University Jaume I in Castellon de la Plana Spain". PhD thesis. University Jaume I in Castellon de la Plana Spain, 2013.

[11] Stephen Fai et al. "Building Information Modeling and Heritage Documentation". In: XXIII CIPA International Symposium, Prague, Czech Republic, 12th-16th September. 2011.

[12] David M. Foxe. "Building Information Modeling for Constructing the Past and Its Future". English. In: APT Bulletin 41.4 (Jan. 2010), pp. 39-45. ISSN: 0848-8525. URL: http://www.jstor.org/stable/41000037 (visited on 02/02/2016).

[13] Simone Garagnani. "Semantic Building Information Modeling and high definition surveys for Cultural Heritage sites". In: DISEGNARECON Special Issue.DoCo 2012 (2012), pp. 297-302.

[14] Simon Haegler, Pascal Müller, and Luc Van Gool. "Procedural Modeling for Digital Cultural Heritage". In: EURASIP Journal on Image and Video Processing 2009.1 (Dec. 2009). ISSN: 1687-5281. DOI: 10.1155/2009/852392.

[15] Karel Jedlička, Otakar Čerba, and Pavel Hájek. "Creation of Information-Rich 3D Model in Geographic Information System - Case Study at the Castle Kozel". In: 13th SGEM GeoConference on Informatics, Geoinformatics And Remote Sensing. June 2013. DOI: $10.5593 /$ sgem2013/bb2.v1/s11.010.

[16] S. Logothetis, A. Delinasiou, and E. Stylianidis. "Building Information Modelling for Cultural Heritage: A review". English. In: ISPRS Annals of the Photogrammetry, Remote Sensing and Spatial Information Sciences II.5 (Jan. 2015), pp. 177-183. ISSN: 2194-9042. DOI: 10.5194/isprsannals-II-5-W3-177-2015.

[17] Petr Macek. Standardní nedestruktivní stavebně-historický průzkum. 2., doplněné vyd. Př́loha časopisu Zprávy památkové péče, roč. 61. - Vydavatel: Státní ústav památkové péče v Praze. Praha: Nakladatelství Jalna, 2001. ISBN: 80-86234-22-3. URL: http:// pamatky-facvut.cz/download/dokumenty/standardni.pdf (visited on 05/13/2015).

[18] Maurice Murphy, Eugene McGovern, and Sara Pavia. "Historic Building Information Modelling - Adding intelligence to laser and image based surveys of European classical architecture". In: ISPRS Journal of Photogrammetry and Remote Sensing. Terrestrial 3D modelling 76 (Feb. 2013), pp. 89-102. ISSN: 0924-2716. DOI: 10.1016/j . isprs jprs . 2012.11 .006$. 
[19] Maurice Murphy, Eugene McGovern, and Sara Pavia. "Historic building information modelling (HBIM)". English. In: Structural Survey 27.4 (Aug. 2009), pp. 311-327. ISSN: 0263-080X. DOI: 10.1108/02630800910985108.

[20] D. Oreni et al. "HBIM for Conservation and Management of Built Heritage: Towards a Library of Vaults and Wooden Bean Floors". English. In: ISPRS Annals of Photogrammetry, Remote Sensing and Spatial Information Sciences II-5/W1 (July 2013), pp. 215221. ISSN: 2194-9050. DOI: 10.5194/isprsannals-II-5-W1-215-2013.

[21] J. I. San José-Alonso et al. "Information and knowledge systems for integrated models in Cultural Heritage". In: Proceedings of the 3rd ISPRS International Workshop 3D-ARCH 2009. Vol. 38. Citeseer, 2009, p. 5. URL: http://citeseerx.ist.psu.edu/viewdoc/ download?doi=10.1.1.445.2498\&rep=rep1\&type=pdf (visited on 02/02/2016).

[22] G. Saygi and F. Remondino. "Management of Architectural Heritage Information in BIM and GIS: State-of-the-art and Future Perspectives". English. In: International Journal of Heritage in the Digital Era 2.4 (Dec. 2013), pp. 695-714. ISSN: 2047-4970. DOI: $10.1260 / 2047-4970.2 .4 .695$.

[23] G. Saygi et al. "Evaluation of GIS and BIM Roles for the Information Management of Historical Buildings". English. In: ISPRS Annals of Photogrammetry, Remote Sensing and Spatial Information Sciences II-5/W1 (July 2013), pp. 283-288. ISSN: 2194-9050. DOI: 10.5194/isprsannals-II-5-W1-283-2013.

[24] Pavel Tobiáš. "An Investigation into the Possibilities of BIM and GIS Cooperation and Utilization of GIS in the BIM Process". In: Geoinformatics FCE CTU 14.1 (June 2015), pp. 65-78. DOI: 10.14311/gi.14.1.5.

[25] B. Watson et al. "Procedural Urban Modeling in Practice". In: IEEE Computer Graphics and Applications 28.3 (May 2008), pp. 18-26. ISSN: 0272-1716. DOI: 10.1109/MCG. 2008.58.

[26] Di Yajing and Wu Cong. "Research on the Building Information Model of the stone building for heritages conservation With the outer south gate of the Ta Keo Temple as an example". In: 2011 International Conference on Electric Technology and Civil Engineering (ICETCE). Apr. 2011, pp. 1488-1491. DOI: 10.1109/ICETCE. 2011.5776479. 
